В. О. Лапіна

\title{
СТРУКТУРА ІНШОМОВНОЇ ПРОФЕСІЙНО ЗОРІЄНТОВАНОЇ МОВЛЕННСВОЇ КОМПЕТЕНТНОСТІ
}

Лапіна В. О. Структура іншомовної професійно зорієнтованої мовленнєвої компетентності.

У статті розглянуто структуру професійно зорієнтованої іншомовної мовленнєвої компетентності у порівнянні зі структурою загальної мовленнєвої компетентності, проаналізовано особливості їх компонентів.

Ключові слова: структура мовленнєвої компетентності, базовий компонент, професійно зоріснтований компонент, особистісно зорієнтований компонент, організаційно-мотиваційний компонент; інформаційно-процесуальний компонент, критеріально-результативний компонент.

Лапина В. А. Структура иноязычной профессионально ориентированной речевой компетентности.

В статье рассмотрена структура профессионально ориентированной иноязычной речевой компетентности в сравнении со структурой общей речевой компетентности, проанализирована специфика их компонентов.

Ключевые слова: структура речевой компетентности, базовый компонент, профессиональноориентированный компонент, личностно-ориентированный компонент, организационно-мотивационный компонент; информационно-процессуальный компонент, критериально-результативный компонент.

Lapina V. O. Structure of foreign language professionally-oriented speech competence.

The article deals with the structure of professionally-oriented foreign language speech competence comparing with the structure of general speech competence, taking into account specific character of their components.

Key words: speech competence structure, basic component, professionally-oriented component, personally-oriented component, organizationally-motivational component, informationally-procedural component, criteria-effective component.

Актуальність проблеми підвищення рівня професійної іншомовної мовленнєвої компетентності майбутніх фахівців пов'язана із соціальноекономічними змінами, що відбуваються в нашій країні: розширення економічних меж України, налагодження міжнародних ділових контактів, створення спільних підприємств, інтенсифікація професійної взаємодії із зарубіжними колегами, утворення єдиного освітянського простору для отримання освіти, проведення досліджень, викладання та стажування в Європейському регіоні. Усі ці перетворення висувають нові вимоги до вищої освіти, особливо до викладання іноземної мови $[1$, с. 11$]$.

Загальноєвропейські Рекомендації з мовної освіти [5], Програма 3 англійської мови для професійного спілкування [8] зорієнтовують діяльність ВНЗ на забезпечення такого рівня володіння іноземною мовою, який дозволяє комунікантам реалізувати обмін інформацією іноземною мовою, а також самостійно здійснити пошук, накопичити й розширити обсяг фахових знань у процесі природного іншомовного професійно зорієнтованого спілкування із зарубіжними фахівцями [5, с. 8].

Теоретико-методичний розгляд наукових праць, що з'ясовують питання мовленнєвої компетентності (I. Родигіна, I. Черезова, І. Волкова) та іiі складових компонентів (3. Бакум, Н. Самохіна й ін.), вивчення психолого-педагогічної теорії механізмів формування мовленнєвої 
культури (О. Леонтьев, М. Жинкін, Л. Петровська), аналіз дисертаційних праць та авторефератів із проблем формування професійно зорієнтованої мовленнєвої компетентності (В. Александров, Н. Самохіна, Н. Сура) дає підстави засвідчити, що структура мовленнєвої компетентності формально споріднена зі структурою мовної компетентності, запропонованою О. Божович.

Отже, ми вважаємо, що структуру мовленнєвої компетентності, як і мовної, теж можна визначити як єдність трьох складових: мовленнєвого досвіду, знань про мову й чуття мови, запропонованих О. Божович як складові компоненти структури мовної компетентності [3].

Якщо мовленнєвий досвід як складник мовної компетентності $\epsilon$ джерелом формування суб'єктивних знань про мову, правил послуговування нею в усній та писемній формах, то як складник мовленнєвої компетентності він уможливлює реалізацію цих знань і правил у процесі найрізноманітніших видів мовленнєвої діяльності. Коли ж знання про мову у складі мовної компетентності покликані скоригувати і збагатити індивідуальні правила, то в контексті мовленнєвої компетентності вони повинні допомогти висловлюватися точно, ясно, коректно, виявити свою індивідуальність тощо. Чуття мови забезпечує безпосереднє розпізнавання якісних особливостей висловлювання; контролює мовленнєві процеси, викликає особливого роду почуття.

Якщо ж брати до уваги професійну спрямованість мовлення, то треба враховувати фахові особливості складових компонентів структури мовленнєвої компетентності.

H. Самохіна, розглядаючи структуру професійно зорієнтованої мовленнєвої компетентності (майбутніх юристів) у своєму науковому дослідженні, виокремлює такі компоненти:

1) базовий компонент - забезпечує ефективну мовленнєву діяльність будь-якого фахівця;

2) професійно зорієнтований компонент - передбачає знання, уміння та навички, досвід мовленнєвої діяльності та рефлексії, які визначають мовленнєву підготовку студентів до здійснення професійної мовленнєвої діяльності;

3) особистісно зорієнтований компонент - формується 3 урахуванням індивідуальних особливостей, схильностей, інтересів студентів, які визначають своєрідність його мовлення, а також впливають на вибір спеціалізації [10].

На нашу думку, запропонована вище структура професійно зорієнтованої мовленнєвої компетентності, яка спрямована у дисертаційному дослідженні Н. Самохіної на формування мовленнєвої компетентності майбутніх юристів, може бути використана для формування та підвищення рівня мовленнєвої компетентності фахівців будь-якої іншої галузі. 
Розглянемо версію структури мовленнєвої компетентності 3 професійною орієнтацією, запропоновану Н. Сурою [11]. У дисертаційній праці витлумачено комунікативну (можемо замінити терміном «мовленнєва», згідно з позицією самої дослідниці $[11$, с. 45]) діяльність студентів під час навчання професійно зорієнтованого спілкування іноземною мовою як систему, до структури якої входять три складові компоненти, а саме:

- організаційно-мотивац̧ійний - система цінностей;

- інформаційно-процесуальний - система знань, умінь і навичок опанування іноземної мови для оволодіння професійними знаннями;

- критеріально-результативний - поетапний контроль рівня сформованості іншомовної професійно орієнтованої комунікативної компетенції студентів [11, с. 52].

Проведений аналіз структури іншомовної професійної мовленнєвої компетентності не претендує на повноту охоплення розглянутої проблеми. Проте, на нашу думку, знання iї складових компонентів та врахування їхніх особливостей можуть допомогти викладачам ВН3 правильно організувати роботу в аудиторії для розвитку та покращення фахових мовленнєвих навичок студентів у процесі вивчення іноземної мови для професійного спілкування.

\section{Література}

1. Александров В. М. Методика інтенсивного навчання інженерів професійно зорієнтованої англійської мови : дис. ... канд. пед. наук : 13.00 .02 / Александров Вячеслав Миколайович. - Запоріжжя, 2008. - 219 c.

2. Бакум 3. П. Теоретико-методичні засади навчання фонетики української мови в гімназії : Монографія / Зінаїда Павлівна Бакум. - Кривий Ріг : Видавничий дім, 2008. - 338 с.

3. Божович Е. Д. Учителю о языковой компетенции школьника : психолого-педагогические аспекты языкового образования / Е. Д. Божович. - М. : Моск. психолого-социальный ин-т, 1998. - 287 с.

4. Волкова І. В. Освітні компетенції. Мовна й мовленнєва компетенції як особлива складова освітніх компетентностей / I. В. Волкова // Матеріали II Міжнародної Інтернет-конференції «Нові виміри сучасного світу».- Мелітополь, 2006. - Том 2. - С. 8-10.

5. Загальноєвропейські Рекомендації з мовної освіти : вивчення, викладання, оцінювання / [наук. ред. проф. С. Ю. Ніколаєва]. - К. : Ленвіт, 2003. - 273 с.

6. Леонтьев А. А. Теория речевой деятельности / А. А. Леонтьев. - М. : Высшая школа, 1971. - 294 с.

7. Петровская Л. А. Компетентность в общении : социально-психологический тренинг / Л. А. Петровская. - М. : Изд-во МГУ, 1989. - 216 с.

8. Програма з англійської мови для професійного спілкування / [Г. Є. Бакаєв, О. А. Борисенко, I. I. Зуєнок та ін.]. - К. : Ленвіт, 2005. - 119 с.

9. Родигіна I. В. Компетентнісно-орієнтований підхід до навчання / I. В. Родигіна. - Х. : Вид. група «Основа», 2005. - 96 с.

10. Самохина Н. В. Формирование речевой компетентности студента-юриста в образовательном процессе вуза : автореф. дис. на соискание науч. степени канд. пед. наук : спец. 13.00.01 «Общая педагогика, история педагогики и образования» / Н. В. Самохина. - Воронеж, 2010. - 25 с.

11. Сура Н. А. Навчання студентів університету професійно зорієнтованого спілкування іноземною мовою : дис. ... канд. пед. наук : 13.00.04 / Сура Наталія Анатоліївна. - Луганськ, 2005. - 227 с.

12. Черезова I. О. Мовленнєва компетентність як одна з головних вимог до індивідуальнопсихологічних особливостей сучасного вчителя / І. О. Черезова // Психологія. - Бердянськ, 2005. - № 2. C. $18-22$. 